\title{
ANALISIS YURIDIS TERHADAP ALASAN PENEMUAN NOVUM PALSU SEBAGAI DASAR PENINJAUAN KEMBALI KEDUA DALAM PERKARA PERDATA
}

\author{
Ulil Manaqib \\ Universitas Islam Negeri Sunan Ampel Jl. A. Yani 117 Surabaya \\ E mail: ulilmanaqib424@gmail.com
}

\begin{abstract}
This article discusses the juridical analysis of the reasons for the discovery of a fake novum as the basis of a second review in a civil case. This study aims to answer the question of how are the reasons for the discovery of a fake novum as the basis for a second review in a civil case? and how are the legal analysis of a reason for the discovery of a fake novum as a the basis for a second review in a civil case. The reason for receiving the second review in the civil case is based on the discovery of a novum which was declared false by the Criminal Judge of the Bandung District Court that has inkracht, is a reason that falls within the criteria of Article 67 letter (a) which reads: "If the decision is based on a lie or a ruse the opposing party that is known after the case has been decided or based on evidence which is later declared to be false by the criminal judge", is not classified as a reason for finding novum or the reason there are two conflicting judicial decisions. Secondly, the second review in the pedata and criminal case is only limited to the reason that there are two Judicial Decisions that are interrelated with one another (SEMA Number 10 Year 2009), so in addition to these reasons, the Supreme Court has never issued a policy related to the second mechanism Judicial Review, including on the grounds that a novum has been legally and convincingly found false by a public court.
\end{abstract}

Keywords: Fake Novum, Review of the two civil cases, Supreme Court.

Abstrak: Artikel ini membahas tentang analisis yuridis terhadap alasan penemuan novum palsu sebagai dasar Peninjauan Kembali kedua dalam perkara perdata, yang bertujuan menjawab pertanyaan tentang bagaimana alasan penemuan novum palsu sebagai dasar Peninjauan kembali kedua dalam perkara Perdata dan bagaimana analisis yuridis terhadap alasan penemuan novum palsu sebagai dasar Peninjauan Kembali kedua dalam perkara perdata. Alasan diterimanya Peninjauan Kembali kedua dalam perkara Perdata didasarkan pada penemuan novum yang dinyatakan palsu oleh hakim Pidana Pengadilan Negeri Bandung yang telah inkracht, merupakan alasan yang masuk dalam kriteria Pasal 67 huruf (a) yang berbunyi: "apabila putusan didasarkan pada suatu kebohongan atau tipu muslihat pihak lawan yang diketahui setelah perkaranya diputus atau didasarkan pada bukti-bukti yang kemudian oleh hakim pidana dinyatakan palsu", bukan tergolong pada alasan telah ditemukannya novum atau alasan

AL-HUKAMA

The Indonesian Journal of Islamic Family Law Volume 09, Nomor 01, Juni 2019; ISSN:2089-7480 
ada dua putusan badan peradilan yang saling bertentangan. Kedua, Peninjauan Kembali kedua dalam perkara Pedata maupun Pidana hanya terbatas pada alasan ada dua putusan Peninjauan Kembali yang antara satu dan lainnya saling berkelindan (SEMA Nomor 10 Tahun 2009), sehingga selain alasan tersebut Mahkamah Agung belum pernah mengeluarkan kebijakan terkait mekanisme Peninjauan Kembali ke-2, termasuk dengan alasan telah ditemukannya novum yang secara sah dan menyakinkan dinyatakan palsu oleh pengadilan umum.

Kata Kunci: Novum palsu, Peinjauan Kembali kedua perkara Perdata, Mahkamah Agung.

\section{Pendahuluan}

Pengaturan peninjauan kembali digunakan dalam hukum acara pidana maupun hukum acara perdata, namun yang menjadi fokus penulis pada penelitian ini adalah pengaturan peninjauan kembali dalam hukum acara perdata. Pengaturan peninjauan kembali dalam hukum acara perdata tersebar dibeberapa aturan terkait, baik yang sudah dinasionalisasi (sesuai nomenklatur Undang-Undang Nomor 12 Tahun 2011 tentang Pembentukan Peraturan Pernndang-undangan) maupun yang belum mendapat landasan yuridis secara formil. Sebaran pengaturan tersebut terdapat dalam HIR, R.Bg, Undang-undang, PERMA dan SEMA, melahirkan sebuah tututan kepada peneggak hukum dalam penggunannya agar memperhatikan kecermatan dan ketelitian dengan komparasi peraturan perundang-undangan yang telah berlaku.1

Peninjauan kembali hadir sebagai saluran hukum luar biasa mempunyai kriteria rigid dalam hal penerimaan perkaranya. Pasal 67 Undang-undang Nomor 3 Tahun 2009 tentang Mahkakah Agung yang selanjutnya disebut UU MA memberikan limitasi terhadap alasan-alasan boleh diajukannya peninjaun kembali. Mengenai limitasi alasan-alasan dapat diajukan peninjaun kembali mendapat validitas hukumnya dalam Pasal 67 UU MA. Keberlakuan pasal 67 berkaitan erat dengan Pasal 66 UU MA yang menerangkan bahwa Peninjaun Kembali (PK) terbatas hanya satu kali pengajuan.2

1 Pasal 66 ayat (2) sampai pasal 77 UU Nomor 3 Tahun 2009 tentang Mahkamah Agung, (Lembaran Negara Republik Indonesia Tahun 2009 Nomor 3, Tambahan Lembaran Negara Republik Indonesia Nomor 4958 ).

2 Ibid 
Keberadaan dua pasal tersebut menegaskan bahwa PK merupakan saluran terakhir yang bersifat extraordinary legal remedy, sehingga prinsip-prinsip yang melekat pada PK harus diberlakukan luar biasa pula sebagaimana pembatasan PK hanya satu kali pengajuan dan limitasi alasan-alasan dapat diterimanya PK.

Faktanya Pasal 66 dan Pasal 67 tidak seutuhnya dapat diterapkan dalam peristiwa konkrit atau peristiwa hukum. Masalah penumpukan perkara, penerimaan perkara pertahunnya yang tinggi dan beban perkara yang rasio penyelesaiannya rendah, membuat Mahkamah Agung harus berpikir ulang untuk mengengentaskan hal tersebut. Salah satu faktor yang disinyalir dan kedepannya akan berpotensi menimbulkan penerimaan perkara di Mahkamah Agung semakin menggunung adalah akibat banyak terselenggaranya PK yang lebih dari satu kali, sehingg terhadap hal tersebut Mahkamah Agung mengeluarkan SEMA Nomor 10 Tahun 2009 yang berisi memerintahkan Pengadilan Pertama dan Banding untuk tidak menerima PK yang kedua kalinya demi kepastian hukum (certainty) dan menegakkan prinsip uapaya hukum luar biasa. SEMA tersebut tidak secara penuh melarang adanya PK untuk kedua kalinya, namun Mahkamah Agung lewat edaran tersebut membolehkan PK untuk kedua kalinya terbatas adanya dua putusan PK yang saling bertentangan meskipun berbeda lingkungan peradilan namun antara yang satu dan lainnya saling berkelindan. Selain langkah preventif untuk mencegah penumpukan perkara lewat pengaturan legal subtance dalam SEMA, Mahkamah Agung juga meneguhkan konsistensi sitem kamar yang selama ini disinyalir kurang beperan efektif sehingga banyak terjadi disparitas putusan terutama putusan PK itu sendiri.

Penegasan sikap MA mengenai mekanisme penerimaan perkara PK yang hanya terbatas satu kali pengajuan dan boleh diajukan untuk yang kedua kalinya dengan catatan ada dua putusan PK yang saling bertentagan kembali ditegaskan lewat hadirnya SEMA Nomor 7 Tahun 2014 sebagai respon sifat erga omnes Putusan Mahkamah Konstitusi Nomor 34/PUU-XI/2013 yang menyatakan Pasal 268 ayat (3) Undang-Undang Nomor 8 Tahun 1981 tentang Hukum Acara Pidana (Lembaran Negara Republik Indonesia Nomor 76 Tahun 1981, Tambahan Lembaran Negara Republik 
Indonesia Nomor 3209) berbunyi: "Permintaan Peninjauan Kembali atas suatu putusan hanya dapat dilakukan satu kali saja" tidak berlaku mengikat dan memerintahkan Pengadilan Tingkat Pertama dan Banding untuk kembali pada SEMA Nomor 10 Tahun 2009 sebagai mekanisme penerimaan PK.

SEMA Nomor 10 Tahun 2009 menjadi satu-satunya pengaturan teknis mengenai mekanisme penerimaan perkara $\mathrm{PK}$, namun di penghujung tahun 2016 telah hadir sebuah putusan Mahkamah Agung yang juga tergolong sebagai landmark decisions pada tahun 2017. Putusan Mahkakamah Agung Nomor 154/PK/TUN/2016 telah memberikan yurisprudensi bahwa Peninjauan Kembali dalam perkara perdata dapat dilakukan kedua kali dengan mekanisme penemuan alat bukti (novum) yang dinyatakan palsu oleh hakim pidana dan terhadapnya telah berkekuatan hukum tetap.

Dalam putusan tersebut hakim mengeluarkan kaidah baru yang berbunyi:

Apabila bukti (novum) yang dijadikan rujukan pada putusan Peninjauan Kembali 1 untuk mengabulkan gugatan, di kemudian hari ternyata bukti (novum) tersebut dinyatakan sebagai surat palsu yang dipalsukan oleh putusan peradilan umum tersebut dapat dijadikan dasar untuk membatalkan putusan Peninjauan Kembali 1 melalui mekanisme Peninjauan Kembali 2.3

Kaidah ini hadir atau timbul dari perkara TUN, meskipun demikian penting penulis melakukan kajian terhadap kaidah tersebut karena secara umum keberlakuan kaidah ini berdampak luas terhadap praktek hukum acara dalam rumpun perdata. Hukum Acara Tata Usaha Negara sesuai Undang-Undanng Nomr 51 Tahun 2009 Tentang Perubahan Kedua Atas Undanng-Undang Nomor 5 Tahun 1986 Tentang Peradilan Tata Usaha Negara yang bersumber dari HIR dan R.Bg, kemudian secara eksplisit hal

3 Bandingkan Putusan Peninjauan Kembali Mahkakamah Agung Nomor 154 PK/TUN/2016 tentang Landmark Decision. 
tersebut dipaparkan dalam penjelasan umum (point 5) UU PTUN yang berbunyi:4

Hukum acara yang digunakan pada Peradilan Tata Usaha Negara mempunyai persamaan dengan hukum acara yang digunakan pada Peradilan Umum untuk perkara perdata, dengan beberapa perbedaan antara lain:

a. pada Peradilan Tata Usaha Negara Hakim berperan lebih aktif dalam proses persidangan guna memperoleh kebenaran materiel dan untuk itu Undang-undang ini mengarah pada ajaran pembuktian bebas;

b. suatu gugatan Tata Usaha Negara pada dasarnya tidak bersifat menunda pelaksanaan Keputusaan Tata Usaha Negara yang disengketakan.

Penjelasan ini hendak mengatakan bahwa hukum acara yang ada di Pengadilan Tata Usaha Negara (PTUN) menggunakan hukum acara perdata selayaknya yang digunakan Peradilan Umum dan Peradilan Agama.

Putusan landmark decisions yang telah menjadi yurisprudensi bahwa peninjaun kembali dalam perkara perdata dapat dilakukan lebih dari satu kali tidak hanya berdampak pada PTUN. Pengadilan Umum atau Pengadilan Negeri yang memeriksa perkara-perkara perdata barang tentu terdampak akibat putusan tersebut. Sama halnya dengan Pengadilan Agama yang mempunyai hukum acara yang sama dengan PTUN juga terdampak akibat putusan tersebut. Efek ribon ini seakan tidak berhenti pada kasus ini saja. Data yang telah dihimpun dari laporan tahunan Mahkamah Agung kurun waktu 2008 sampai 2018 kecenderungan pengajuan permohonan peninjauna kembali mengalami tren kenaikan baik perkara pindana maupun perdata.5 Terlebih untuk Pengadilan Agama kecenderungan tren kenaikan perkara peninjauan kembali. Perkara-

4 Penjelasan Umum Undang-Undang Nomor 51 Tahun 2009 Tentang Perubahan Kedua Atas Undang-Undang Nomor 5 Tahun 1986 Tentang Peradilan Tata Usaha Negara (Lembaran Negara Republik Indonesia Tahun 2009 Nomor 160, Tambahan Lembaran Negara Republik Indonesia Nomor 5079) 5 Statistik Data Perkara Mahkamah Agung diakses dari: http://leip.or.id/statistikdata-perkaramahkamah-agung, pada tanggal 01 April 2019, pukul 07:28 WIB. 
perkara yang menjadi kompentsi absolut Pengadilan Agama juga berpotensi menambah beban bersidang Hakim Agung. Saat ini perceraian, sengketa harta bersama, sengketa waris dan hibah menjadi perkara yang aktif masuk buku penerimaan perkara di Pengadilan Agama mayoritas di Indonesia, sehingga potensi beban kerja Hakim Agung untuk memutus peninjaun kembali tidak dapat dielakkan.

Konsistensi lembaga peradilan yang menjadi tujuan utama para pencari keadilan guna memperoleh keadilan yang cepat, sederhana dan biaya murah, jauh dari indikator pencapain ketika penumpukan perkara ini masih terjadi. Akses peninjauan kembali dapat dilakukan lebih dari satu kali berpotensi menjadi penyumbang terbesar penumpukan perkara peninjauan kembali di Mahakamh Agung yang memiliki Hakim Agung terbatas dengan jadwal sidang yang padat.

Makna Peninjauan Kembali sebagai upaya hukum luar biasa terlebih dalam perkara perdata seyogyanya dilakukan hanya satu kali terkandung maksud untuk menjamin kepastian hukum. Praktik hukum yang selalu berada di jalur yang berbeda dengan teori hukum menjadi menarik dalam kajian ilmiah, agar das sollen dan das sein bisa selaras.

Berangkat dari uraian tersebut diatas, penyusun merasa perlu untuk mengadakan penelitian lebih lanjut. Bagaimana alasan penemuan alat bukti (novum) palsu sebagai dasar Peninjauan Kembali kedua dalam perkara perdata. Maka penulis membuat skripsi dengan judul "Analisis Yuridis Terhadap Alasan Penemuan Novum Palsu sebagai Dasar Peninjauan Kembali Kedua dalam Perkara Perdata"

\section{Alasan Peninjauan Kembali}

Ketentuan Pasal 67 UU MA telah mengatur dan membatasi alasan permohonan PK hanya pada yang telah disebut secara enumeratif satu persatu dalam pasal tersebut. Kebutuhan untuk menambahkan atau mengurangi menjadi sebuah tindakan yang nyata-nyata bertentangan dengan ketentuan Pasal 67 UU MA yang berbunyi "Permohonan peninjauan kembali putusan perkara perdata yang telah memperoleh kekuatan hukum tetap dapat diajukan hanya berdasarkan alasan-alasan sebagai berikut". 
Klausula “...hanya berdasarkan alasan-alasan sebagai berikut", harus dibaca bahwa alasan-alasan PK terbatas pada ketentuan yang telah disebutkan dalam Pasal 67 UU MA. Kemudian pasal ini dimaknai bersifat limitatif (restrictive), padanya melekat ketentuan yang rigid agar lembaga peninjauan kembali tidak berubah menjadi layaknya lembaga sampah karena ketika tidak dibatasi, dimungkinkan akan banyak sekali perkara yang masuk ke tingkat peninjauan kembali.

Sehubungan dengan hal tersebut berikut akan dijelaskan satu persatu mengenai alasan-alasan yang bersifat limitatif tadi sesuai dengan Pasal 67 UU MA dibawah ini

1. Putusan Didasarkan pada Suatu Kebohongan atau Tipu Muslihat dari Pihak Lawan

Putusan yang dimintakan PK merupakan produk pengadilan yang mengandung kebohongan atau tipu muslihat. Yahya harahap mencoba mengeluarkan rumusan Pasal 67 huruf a UU MA tersebut kedalam dua kriteria sebagai berikut:6

a) Putusan didasarkan pada suatu kebohongan atau tipu muslihat pihak lawan, dan kebohongan atau tipu muslihat itu diketahui setelah perkaranya putus, atau

b) Putusan didasarkan pada bukti-bukti yang kemudian oleh hakim pidana dinyatakan palsu.

Kebohongan atau tipu muslihat yang dimaksud diperoleh setelah perkara diputus, bukan diperoleh saat pemeriksaan pada tingkat pertama, banding maupun kasasi. Kemungkinan lain yang bisa juga terjadi yakni muncul atau terbutnya sebuah putusan pidana oleh pengadilan pidana yang menyatakan bukti-bukti atau salah satu bukti yang diajukan pihak lawan dalam proses pemeriksaan adalah palsu. Terkandung maksud yaitu terhadap bukti-bukti yang telah disampaikan selam proses pemeriksaan banding dan kasasi, bukti-bukti tersebut dianggap sah dan mem[unyai kekuatan pembuktian dan memenuhi batas minimal pembuktian. Kemudian seiring berjalannya waktu setelah putusan tersebut BHT ada pihak yang mencurigai bahwa buktibukti yang disampaikan dalam proses peradilan (banding

6 M. Yahya harahap, Kekuasaan Mabkamah Agung Pemeriksaan Kasasi dan Peninjauan Kembali Perkara Perdata, 450 
maupun kasasi) selama ini disinyalir tidak dapat dipertanggung jawabkan atau palsu, oleh karenanya pihak yang merasa dirugikan atau pihak lain yang berkepentingan, menempuh saluran pidana dan keyakinan tersebut juga menguatkan keyakinan hakim pengadilan pidana sehingga menyatakan surat atau bukti tersebut palsu. Praktik inilah yang kemudian jamak ditemui dalam alasan pengajuan PK, karena apabila menggunakan alasan yang didasarkan pada kebohongan dan tipu muslihat secara kongkrit dan obyektif sulit untuk mewujudkannya, kecuali dikonstruksi secara rinci sehingga alasan kebohongan dan tipu muslihat tersebut benar-benar obyektif.

2. Ditemukan Surat-Surat Bukti yang Bersifat Menentukan atau Novum

Alasan kedua ini terdapat dalam Pasal 67 huruf b yang berbunyi, "Apabila setelah perkara diputus, ditemukan suratsurat bukti yang bersifat menentukan yang pada waktu perkara diperiksa tidak dapat ditemukan". Setidaknya ada dua hal penting dari ketentuan ini, yakni: a. ditemukan surat-surat bukti yang bersifat menetukan; b. surat-surat bukti itu telah ada sebelum gugatan atau sebelum perkara diajukan ke pengadilan, namun selama proses pemeriksaan berlangsung mulai dari tingkat pertama, banding maupun kasasi tidak ditemukan. Faktor yang menyertai bukti tersebut tidak ditemukan beragam, mungkin pada saat pemeriksaan hilang atau tidak diketahui tempat penyimpanannya dan sebagainya, sehingga tidak bisa diajukan dalam proses persidangan. Menjadi menentukan apabila bukti tersebut ditemukan kembali ketika putusan telah BHT.

Praktik peradilan menyebut alasan PK sebagaimana termaktub dalam Pasal 67 huruf b UU MA ini juga sebagai novum. Novum atau novi berasal dari bahasa latin yang memiliki arti sesuatu yang baru, fakta baru, termasuk juga hukum baru. Novum bahasa latin, mempunyai istilah lengkap sebagai noviter verventra yang dalam bahasa Inggris berarti newly discover fact with are usually a law to be introduced in case, even after reading are closed. Kemudian istilah ini diadopsi ke dalam sistem hukum Belanda sehingga dikenal dengan istilah Juridische Lexicon, The Legal Lexicon 
Nederlands-Eslish,7yang mengartikannya dengan fresh fact, new point pf law. Kesemuanya mempunyai arti bukti baru atau keadaan baru, atau dalam Kamus Hukum, Edisi lengkaps mengartikan novum dengan istilah alasan yang baru muncul.

Persandingan antara teori yang telah disampaikan di banyak Negara yang menggunakan istilah novum dengan rumusal Pasal 67 huruf b UU MA sedikit berbeda. Ketentuan tersebut pada dasarnya menhendaki pemaknaan bukti baru terbatas pada surat yang telah ada sebelum perkara diperiksa yang tidak ditemukan selama proses pemeriksaan berlangsung.

Kemudian agar pemaknaan terhadap Pasal 67 huruf b ini jelas dan terang, Yahya Harahap berdasarkan pembacaan ketentuan-ketentuan yang berkaitan, memberikan garis dan rambu terhadap ketentuan ini kedalam empat hal, yakni:9

a. Penerapan alasan ini terbatas pada bentuk alat bukti surat

b. Surat bukti yang memenuhi syarat alasan PK, harus bersifat menentukan

c. Hari dan Tanggal surat bukti itu ditemukan, harus dinyatakan di bawah sumpah dan disahkan pejabat yang berwenang

d. Surat bukti itu telah ada sebelum proses pemeriksaan perkara

3. Putusan Mengabulkan Sesuatu Hal yang Tidak Dituntut (Ultra Vires) atau Lebih Daripada yang Dituntut (Ultra Petita)

Alasan ini diatur dalam dalam Pasal 67 huruf c, yang berbunyi:10 "Apabila telah dikabulkan sesuatu hal, yang tidak dituntut atau lebih daripada yang dituntut". Setidaknya dari klausula diatas dapat diklasifikasikan kedalam dua bagian, yakni a. putusan mengabulkan sesuatu hal yang tidak dituntut (ultra vires); b. putusan melebihi dari apa yang dituntut (ultra petita).

7 A. Ven Den End, Jurisdiction Lexicon, Gateway, 1995, 372 dalam M. Yahya Harahap, Kekuasaan Mabkamah Agung Pemeriksaan Kasasi dan Peninjauan Kembali Perkara Perdata, 454

8 Editor Arif S, 276 dalam M. Yahya Harahap, Kekuasaan Mabkamah Agung Pemeriksaan Kasasi dan Peninjauan Kembali Perkara Perdata, 454

9 M. Yahya harahap, Kekuasaan Mabkamah Agung Pemeriksaan Kasasi dan Peninjauan Kembali Perkara Perdata, 453

10 Pasal 67 huruf c, Undang-Undang Nomor 3 Tahun 2009 Tentang Mahkamah Agung 
Asas ultra petita atau ultra vires merupakan derivasi dari asas yang terdapat dalam hukum acara perdata bahwa hakim bersifat pasif, yaitu suatu asas yang tidak menghendaki hakim untuk mengadili sebuah perkara yang tidak diajukan kepadanya atau dalam konteks ini tidak diajukan ke pengadilan.11 Antara ultra vires maupun ultra petita telah secara terang dan jelas tidak dibenarkan oleh peraturan perundang-undangan. Tindakan ultra vires terang telah dilarang dalam Pasal $50 \mathrm{Rv}$ maupun dalam Pasal 178 ayat (3) HIR, sedangkan tindakan ultra petita atau ultra petitum patium juga dilarang sesuai dengan ketentuan Pasal $50 \mathrm{Rv}$ maupun Pasal 178 ayat (3) dan Pasal 189 ayat (3) RBg. Kemudian karena dalam putusan-putusan peradilan sering ditemui praktek ultra petita maka dalam alasan PK mengakomodir para pencari keadilan untuk dapat mengajukan permohonan PK apabila ditemui sebuah putusan seorang hakim yang mengabulkan suatu hal yang tidak dituntut atau lebih daripda yang dituntut.

4. Terdapat Suatu Bagian dari Tuntutan yang Belum Diputus Tanpa Dipertimbangkan Sebabnya

Ketentuan Pasal 67 huruf d memuat alasan PK keempat yang berbunyi,12"Apabila mengenai satu bagian dari tuntutan belum diputus tanpa dipertimbangkan sebab-sebabnya". Alasan ini muncul karena sebelumnya dalam Pasal $50 \mathrm{Rv}$, Pasal 178 ayat (2) HIR dan Pasal $189 \mathrm{RBg}$, memerintahkan hakim wajib mengadili atau memutus tentang semua bagian, sehingga ketika perkara diputus atau diadili tanpa memperhitungkan provisi, sita atau permintaan putusan serta-merta, terhadapnya tanpa mempertimbangkan sebab-sebanya, maka putusan ini dapat dijadikan sebagai alasan PK, sebagaimana rumusan Pasal 67 huruf d. Putusan lain yang dapat dikategorikan sebagai putusan yang yang tidak mempertimbangkan sebab-sebabnya yang kemudian dapat diajukan sebagai alasan PK (sebagaimana rumusan Pasal 67 huruf d) adalah hakim lalai dalam memutus gugatan rekonvensi (counterclaim) yang diajukan tergugat tanpa

11 Sunarto, Peran Aktif Hakim dalam Perkara Perdata, Jakarta: Prenada Media, 2017), 36

12 Pasal 67 huruf d, Undang-Undang Nomor 3 Tahun 2009 Tentang Mahkamah Agung 
dipertimbangkan alasannya mengapa gugatan rekovensi itu tidak diputus. 13

5. Terdapat Putusan yang Bertentangan Antara yang Satu dengan yang Lain

Alasan PK yang kelima ini terdapat dalam Pasal 67 huruf e yang berbunyi:14 "Apabila antara pihak-pihak yang sama mengenai suatu soal yang sama, atas dasar yang sama oleh pengadilan yang sama atau sama tingkatnya telah diberikan putusan yang bertentangaan suatu dengan yang lain”. Klausula ini dapat terpenuhi apabila syarat-syarat yang mengikutinya dan bersifat kumulatf. Adapun syarat-syarat tersebut adalh sebagai berikut:15

a. Terdapat dua atau lebih putusan yang saling bertentangan;

b. Pihak yang terlibat dalam putusan yang saling bertentangan tresebut adalah sama;

c. Soal dan dasar yang digunakan sama;

d. Diperiksa oleh pengadilan yang sama atau sama tingkatnya

Syarat ini menentukan putusan yang saling bertentangan itu dijatuhkan oleh:

1) Pengadilan yang sama, atau

2) Pengadilan yang sama tingkatanya

e. Putusan yang terakhir dan bertentangan itu telah BHT

6. Terdapat Suatu Kekhilafan Hakim atau Suatu Kekeliruan yang Nyata

Kekhilafan menjadi entry point dalam alasan PK yang keenam ini. Hakim sebagai wakil Tuhan di Bumi sepatutnya dimaknai dalam menjalankan profesinya, namun dalam dimensi lain hakim tetaplah seorang manusia yang tidak bisa dipisahkan dari salah dan lupa, sehingga menjadi wajar ketika alasan kekhilafan ini menajadi primadona untuk diusung sebagai alasan PK itu sendiri. Spectrum yang begitu beragram dapat diperoleh

13 M. Yahya harahap, Kekuasaan Mabkamah Agung Pemeriksaan Kasasi dan Peninjauan Kembali Perkara Perdata, 461

14 Pasal 67 huruf e, Undang-Undang Nomor 3 Tahun 2009 Tentang Mahkamah Agung

15 M. Yahya harahap, Kekuasaan Mabkamah Agung Pemeriksaan Kasasi dan Peninjauan Kembali Perkara Perdata, 461-465 
dari putuan yang memuat unsur kekhilafan, karena pada setiap putusan memungkinkan untuk direkontruksi atau direkayasa sebagai putusan yang memuat unsur kekhilafan. Sebelum UU MA dibentuk banyak bermunculan PK dengan alasan ini, sehingga sekitar tahun 1990 muncul wacana untuk menghapuskan alasan ini dari alasan PK dalam RUU MA, namun sangat disayangkan pada pengesahan UU MA dan sampai sekarang masih tercantum ketentuan Pasal 67 huruf f sebagai alasan PK.16

Setidaknya upaya yang bisa dilakukan penegak hukum agar pasal ini efektif yaitu dengan memberi batasan dan ruang lingkup yang jelas tehadap alasan PK keenam ini, yakni dengan batasan atau ruang lingkup sebagai berikut:17 a. penafsiran atau pendapat bukan termasuk kekhilafan atau kekeliruan nyata; b. membenarkan sesuatu yang tidak memenuhi ketentuan hukum.

\section{Ratio Legis Peninjauan Kembali Terbatas Satu Kali dalam Perkara Perdata}

1. Undang-Undang Mahkamah Agung

Pengaturan peninjauan kembali mempunyai validitas hukum pertama kali dalam Undang-Undang Nomor 14 Tahun 1985 Tentang Mahkamah Agung yang selanjutnya disebut dengan UU MA, begitupun mengenai tentang pengaturan peninjaun kembali terbatas hanya satu kali terdapat dalam Pasal 66 ayat (1) UU MA yang berbunyi:18 "Permohonan Peninjauan kembali dapat diajukan hanya 1 (satu) kali;". Praktek hukum yang begitu dinamis membuat UU MA harus dilakukan pembaharuan, dan seperti kita ketahui bersama bahwa UU MA telah mengalami 2 (dua) kali perubahan dengan Undang-Undang Nomor 3 Tahun 2009 yang terakhir disahkan yang mengatur tentang Mahkamah Agung, begitupun UU MA telah beberapa kali mengalami perubahan, namun tidak diikuti oleh pembatasan PK yang hanya satu kali sebagaimana terdapat dalam pasal 66 diatas. Kemudian

16 Ibid, 467

17 Ibid, 466-468

18 Pasal 66 ayat (1), Undang-Undang Nomor 3 Tahun 2009 Tentang Mahkamah Agung 
hal ini dimaknai bahwa pembentuk undang-undang menghendaki bahwa pengaturan PK sepatutnya terbatas hanya satu kali pengajuan.

2. Surat Edaran Mahkamah Agung (SEMA)

Berikut kedua SEMA yang telah diterbitkan sebagai respon praktik PK yang beberapa kali diajukan untuk kedua kalinya:19

a. SEMA Nomor 10 Tahun 2009

Surat Edaran ini dikeluarkan pada tanggal 12 Juni 2009 sebagai bentuk penegakan asas kepastian hukum dan juga sebagai respon atas kerisauan penumpukan perkara di MA. Kemudian SEMA ini memberi petunjuk kepada Pengadilan Tingkat Pertama untuk memeberi penetapan tidak menerima permohonan PK apabila permohonan tersebut diajukan kedua kalinya. Batasan PK yang hanya boleh dilakukan satu kali tidak berlaku apabila terdapat dua putusan PK yang saling bertentangan dan salah satunya diajukan, maka Mahkamah berkewajiban menerima permononan tersebut. Kebijakan yang demikian bukan berarti Mahkamah Agung tidak konsisten terhadap pembatasan PK, namun karena keadaan yang demikian timbul berawal dari manajemen penerimaan perkara yang kurang optimal sehingga dimungkinkan ada dua putusan PK yang saling bertentangan. Menghindari keadaan yang demikian, Direktorat Perdata harus memaksukkan kedua permohonan itu kedalam berkas perkara yang bersangkutan. Kedua permohonan itu tidak dipisah berdiri sendiri menjadi dua berkas. Perkara tersebut diserahkan kepada satu Majelis yang sama. Proses pemeriksaannya dilakukan serentak, kemudian dari hasil pemeriksaan tersebut permohonan bisa ditolak dan bisa dikabulkan atau kedua-duanya ditolak.20

b. SEMA Nomor 7 Tahun 2014

Surat Edaran ini diterbitkan tanggal 31 Desember 2014 sebagai respon terbitnya putusan Mahkamah Konstitusi

19 Kumpulan Surat Edaran Mahkamah Agung, diakses dari: http://bawas.mahkamahagung.go.id/portal/surat-edaran-mahkamah-agung, pada tanggal 26 Juni 2019, Jam 04.23

20 Mahakamah Agung, Surat Edaran Nomor 10 Tahun 2009 Tentang Pengajuan Permohonan Peninjauan Kembali (Nomor Surat: 10/Bua.6/Hs/SP/VI/2009) 
Nomor 34/PUU-XI/2013 tanggal 6 Maret 2014 butir 1.2 dinyatakan bahwa pasal 268 ayat (3) Undang-Undang Nomor 8 Tahun 1981 tentang Hukum Acara Pidana (Lembaran Negara Republik Indonesia Tahun 1981 Nomor 78, Tambahan Lembaran Negara Republik Indonesia Nomor 3209) tidak mempunyai kekuatan hukum mengikat, sehingga dalam judulnya surat edaran ini berisi tentang Pengajuan Permohonan Peninjauan Kembali dalam Perkara Pidana. Meskipun putusan Mahkamah Konstitusi bersifat final dan mengikat serta bersifat erga omnes,21 dalam edaran tersebut Mahkamah Agung berpendapat bahwa pengajuan PK tebatas hanya satu kali dan kosisten dengan pengecualian PK yang boleh diajukan lebih dari satu kali sebagimana SEMA Nomor 10 Tahun 2009.

Kaitannya dalam konteks ini saja bahwa perkara pidana yang seyogyanya lebih progresif dalam proses pemeriksaan dikarenakan untuk menemukan kebenaran materiil22 termasuk dalam proses peninjauan kembali tidak bisa diterapkan pengajuan permohonan peninjauan kembali untuk yang kedua kali atau selebihnya, apalagi dengan perkara perdata yang dalam pemeriksaanya berfungsi untuk menemukan kebenaran formil.23

3. Putusan Mahkamah Konstitusi Nomor 34/PUU-XI/2013

Putusan tersebut dimihonkan oleh Pemohon: 1) Antasari Azhar, S.H, M.H; 2) Ida Laksmiwaty, S.H; 3) Ajeng Oktarifka Antasariputri, dengan jenis perkara berupa pengujian undangundang 8 Tahun 1981 tentang Hukum Acara Pidana terhadap undang-undang Dasar 1945. Permohonan tersebut berisi pokok perkara Pasal 268 ayat (3) undang-undang Nomor 8 Tahun 1981 tentang Hukum Acara Pidana yang menyatakan, “(3) Permintaan

21 Maruarar Siahaan, "Peran Mahkamah Konstitusi Dalam Penegakan Hukum Konstitusi”, Jurnal Hukum Nomor 3, Volume, 16 juli 2009, hlm. 359

22 Tamat Zaifudin, Kebenaran Formal Dalam Pembuktian Di Pengadilan Agama , Jurnal Aktualita, Vol.1 No.2 (Desember) 2018 hal. 330-349

23 Mahakamah Agung, Surat Edaran Nomor 7 Tahun 2014 Tentang Pengajuan Permohonan Peninjauan Kembali Dalam Perkara Pidana (Nomor Surat: 165/Bua.6/Hs/SP/XII/2014) 
peninjauan kembali atas suatu putusan hanya dapat dilakukan satu kali saja" bertentangan dengan UUD NRI 1945, yakni Pasal 1 ayat (3), Pasal 24 ayat (1), Pasal 28A, dan Pasal 28C, Pasal 28D ayat (1) UUD NRI 1945, dalam amar putusannya mengabulkan permohonan Para Pemohon, sehingga PK dalam perkara pidana bisa diajukan bebrapa kali mengingat:24

a. Karakter kebenaran mengenai peristiwa yang menjadi dasar dalam putusan perkara pidana adalah kebenaran materiil berdasarkan pada bukti yang dengan bukti-bukti tersebut meyakinkan hakim, yaitu kebenaran yang secara rasional tidak terdapat lagi keraguan di dalamnya karena didasarkan pada bukti yang sah dan meyakinkan. Oleh karena itu, dalam perkara pidana bukti yang dapat diajukan hanya ditentukan batas minimalnya, tidak maksimalnya. Dengan demikian, untuk memperoleh keyakinan dimaksud hukum harus memberikan kemungkinan bagi hakim untuk membuka kesempatan diajukannya bukti yang lain, sampai dicapainya keyakinan dimaksud; Sejalan dengan karakter kebenaran tersebut di atas, karena secara umum, KUHAP bertujuan untuk melindungi HAM dari kesewenang-wenangan negara, terutama yang terkait dengan hak hidup dan kebebasan sebagai hak yang sangat fundamental bagi manusia sebagaimana ditentukan dalam UUD 1945 maka dalam mempertimbangkan PK sebagai upaya hukum luar biasa yang diatur dalam KUHAP haruslah dalam kerangka yang demikian, yakni untuk mencapai dan menegakkan hukum dan keadilan. upaya pencapaian kepastian hukum sangat layak untuk diadakan pembatasan, namun upaya pencapaian keadilan hukum tidaklah demikian, karena keadilan merupakan kebutuhan manusia yang sangat mendasar, lebih mendasar dari kebutuhan manusia tentang kepastian hukum.

b. Bahwa Pasal 28 J ayat (2) UUD 1945 menyatakan, "Dalam menjalankan hak dan kebebasannya, setiap orang wajib tunduk kepada pembatasan yang ditetapkan dengan penghormatan atas hak dan kebebasan orang lain dan untuk

24 Iktisar Putusan Mahkamah Konstitusi Nomor 34/PUU-XI/2013 
memenuhi tuntutan yang adil sesuai dengan pertimbangan moral, nilai-nilai agama, keamanan, dan ketertiban umum dalam suatu masyarakat demokratis", menurut Mahkamah, pembatasan yang dimaksud oleh Pasal 28J ayat (2) UUD 1945 tersebut tidak dapat diterapkan untuk membatasi pengajuan PK hanya satu kali karena pengajuan PK dalam perkara pidana sangat terkait dengan hak asasi manusia yang paling mendasar yaitu menyangkut kebebasan dan kehidupan manusia. Lagi pula, pengajuan PK tidak terkait dengan jaminan pengakuan, serta penghormatan atas hak dan kebebasan orang lain dan tidak terkait pula dengan pemenuhan tuntutan yang adil sesuai dengan pertimbangan moral, nilai-nilai agama, keamanan, dan ketertiban umum dalam masyarakat yang demokratis.

c. Bahwa benar dalam ilmu hukum terdapat asas litis finiri oportet yakni setiap perkara harus ada akhirnya, namun menurut Mahkamah, hal itu berkait dengan kepastian hukum, sedangkan untuk keadilan dalam perkara pidana asas tersebut tidak secara rigid dapat diterapkan karena dengan hanya membolehkan peninjauan kembali satu kali, terlebih lagi manakala ditemukan adanya keadaan baru (novum). Hal itu justru bertentangan dengan asas keadilan yang begitu dijunjung tinggi oleh kekuasaan kehakiman indonesia untuk menegakkan hukum dan keadilan (Pasal 24 ayat (1) UUD 1945) serta sebagai konsekuensi dari asas negara hukum.

\section{Dinamika Permohonan Kasasi dan Peninjauan Kembali Perkara Perdata}

Perubahan kondisi sosial, budaya, politik, ekonomi, serta tingkat pendidikan dan kesadaran hukum di Indonesia dewasa ini berpengaruh tehadapa penambahan jumlah perkara yang masuk ke pengadilan. Jika saat ini masyarakat pengguna sistem peradilan hanya mereka yang tingkat pendidikannya cukup tinggi, memiliki kemampuan ekonomi di atas rata-rata, 25 terutama dengan perbaikan di sektor pendidikan dan kesadaran hukum masyarakat, maka di

25 World Bank, Evaluating Legal Institutions: Performance Measures Opinion Surveys Empirical Research, hal. 21 
masa mendatang hampir dapat dipastikan akan lebih banyak lagi masyarakat yang akan menggunakan peradilan sebagai jalur penyelesaian sengketanya. Hal ini berarti bahwa jumlah perkara yang masuk ke pengadilan dan dimintakan kasasi bahkan peninjauan kembali akan semakin besar. Sedangkan disisi lain bahwa upaya peradilan harus diposisikan sebagai ultimum remedium, sehingga marwah peradilan bisa berjalan efektif dan tidak dinodai dengan perkara yang dimensi hukumnya berskala ringan yang seharusnya bisa diselesaikan dengan jalan damai dan segala upaya lain diluar peradilan.

Perkembangan hukum ditubuh Mahkamah Agung dalam hal laporan penerimaan perkara yang masuk ke pengadilan cukup dinamis, tidak hanya memiliki dimensi yang relatif sederhana permasalahan hukumnya dan dapat diputus dengan sederhana dan cepat seperti hutang-piutang, narkotika, judi, dan lain sebagainya, namun juga perkara-perkara yang mempunyai aspek konstitusional, menyangkut kepentingan publik atau menyangkut perkembangan hukum baru. Praktek class action setidaknya menggambarkan secara nyata bahwa individu-individu saat ini mengalami kemajuan dalam hal sudut pandang pentingnya hukum, seperti halnya masalah pertanahan, sengketa waris dan bahkan perlindungan konsumen, meskipun nilai ekonomisnya kecil, tapi karena dipandang memiliki nilai hukum yang mungkin besar, sehingga layak untuk diperjuangkan di jalur peradilan. 26 Belum lagi jika kita memperhitungkan peluang penggunaan hak-hak konstitusional yang diatur cukup rinci dalam UUD 1945 untuk menggugat pelanggaran hak-hak tersebut ke pengadilan. Di Negara berkembang lain seperti India atau Afrika Selatan, tidak sedikit masyarakat yang menempuh proses hukum ke pengadilan untuk mendapatkan hak-hak yang dijamin langsung dalam konstitusi, seperti kebebasan beragama, perumahan, lingkungan yang layak atau kesehatan. Pendeknya, seiring dengan perubahan ekonomi, sosial, budaya, dan politik, baik

26 Misalnya perkara sengketa konsumen yang kerap diajukan ke pengadilan oleh advokat David Tobing. Penjelasan lebih lanjut mengenai kasus-kasus yang pernah ditanganinya, dilihat dalam Lembaga Kajian Keilmuan Fakultas Hukum Universitas Indonesia, "Konsep 'Small Claim Court dalam Sistem Peradilan Indonesia, Mungkinkah?” (2010), hal. 59-66. 
di tingkat masyarakat maupun negara, bisa dipastikan akan semakin banyak perkara yang akan dimintakan kasasi dan peninjauan kembali ke Mahkamah Agung dimasa mendatang. Sebagiannya mungkin perkara-perkara yang yang dimensi hukumnya kecil namun sebagian lainnya menyangkut permasalahan-permasalahan hukum serius yang memang perlu diputus oleh MA. Tanpa adanya respon cepat dari pembuat UU untuk membatasi pembatasan perkara yang dapat masuk ke MA, bukan mustahil dalam beberapa tahun ke depan tunggakan perkara MA akan semakin membengkak dan menimbang praktek selama ini- semakin mustahil kita berharap MA dapat membuat putusan-putusan yang mendalam, elaboratif dan memiliki kualitas sebagai landmark decisions.

Perkara yang masuk ke Mahkamah Agung dari berbagai jenis perkara di tahun 2018 meyentuh angka 14.726. Sebetulnya angka ini mengalami penurunan dari tahun 2017 sebesar 25\% dengan jumlah perkara 18.336. Permohonan perkara kasasi dan peninjauan kembali di Mahkamah Agung cenderung fluktuatif, namun lebih dominan mengalami kenaikan, baik permohonan kasasi maupun peninjauan kembali. Blue print Mahkamah Agung Pembaharuan Peradilan 20102035, yang menjadi salah satu fokus pembenahan adalah masalah penyelesaian tunggakan perkara yang menggurita, termasuk di Mahkamah Agung sendiri. Berikut data yang dihimpun dari laporan tahunan Mahkamah Agung kurun waktu tahun 2015-2018 untuk perkara kasasi dan peninjauan kembali.

Tabel 1

Keadaan Perkara Kasasi dan Peninjauan Kembali Mahkamah Agung (Tahun 2015-2018)27

\begin{tabular}{|c|c|c|c|c|c|c|c|c|c|}
\hline \multirow{2}{*}{ No } & \multirow{2}{*}{$\begin{array}{c}\text { Jenis } \\
\text { Perkara }\end{array}$} & \multicolumn{9}{|c|}{ Laporan Tahun } \\
\cline { 3 - 10 } & & \multicolumn{2}{|c|}{2015} & \multicolumn{2}{|c|}{2016} & 2017 & \multicolumn{3}{|c|}{2018} \\
\hline 1. & Perdata & 3.615 & 656 & 3.817 & 788 & 3.536 & 897 & 4.022 & 1.053 \\
\hline 2. & $\begin{array}{c}\text { Perdata } \\
\text { Khusus }\end{array}$ & 854 & 125 & 1.125 & 146 & 1.534 & 169 & 1.248 & 256 \\
\hline 3. & $\begin{array}{c}\text { Perdata } \\
\text { Agama }\end{array}$ & 861 & 101 & 822 & 123 & 852 & 110 & 807 & 75 \\
\hline 4. & Pidana & 1.750 & 101 & 1.500 & 108 & 1.446 & 99 & 1.385 & 81 \\
\hline 5. & $\begin{array}{c}\text { Pidana } \\
\text { Khusus }\end{array}$ & 3.016 & 223 & 2.834 & 245 & 2.904 & 287 & 3.452 & 315 \\
\hline
\end{tabular}

27 Laporan Tahunan Mahkamah Agung 2015-2018 


\begin{tabular}{|c|c|c|c|c|c|c|c|c|c|}
\hline 6. & Militer & 316 & 31 & 372 & 20 & 554 & 18 & 338 & 30 \\
\hline 7. & PTUN & 697 & 1.518 & 575 & 2.057 & 570 & 2.395 & 672 & 160 \\
\hline
\end{tabular}

Perkara pidana masih menjadi primadona penyumbang permohonan ke Mahkamah Agung, tercatat tahun 2018 untuk perkara Kasasi mengalami kenaikan 9\% atau sebesar 4.837 perkara yang awalnya 4.350 perkara. Kenaikan ini juga terjadi dalam perkara peninjaun kembali, setidaknya di tahun 2018 tercatat kenaikan jumlah permohonan peninjuan kembali yakni sebesar 3\% atau sebesar 396 yang awalnya 386. Tren kenaikan jumlah perkara juga ditunjukan untuk jenis perkara perdata baik Perdata Umum maupun Perdata Khusus. Kurun waktu 4 (empat) tahun terakhir tren kenaikan itu ditunjukan meskipun jumlahnya tidak signifikan seperti halnya jenis perkara pindana, namu perkara Perdata umum dan khusus menduduki penyumbang kedua dengan catatan kenaikan rata-rata di angka 10\%. Tahun 2018 saja tercatat 1.309 perkara yang masuk atau naik sebesar 19\% dari tahun 2017 yang sebesar 1.066 .

Kecenderungan mengalami penurunan ditampilkan oleh perkara PTUN dan Perdata Agama, kendati demikian untuk perkara PTUN masih menyentuh angka ribuan, untuk permohonan peninjauan kembali ditahun 2017 sampai diangka 2.395 namun mengalami penurunan drastis di tahun 2018 menjadi 215. Turun sebesar 1014\%, dan kemudian ini menjadi capaian yang signifikan. Dibandingkan dengan jenis perkara Pidana, Perdata dan PTUN, untuk jenis perkara Perdata Agama masih tergolong paling rendah mengisi permohonan di Mahkamah Agung baik tingkat kasasi maupun peninjauan kembali. Tren kenaikan ditunjukan ditahun 2016, menyentuh angka 120 atau naik sebesar 16\% dibanding tahun 2015 , namun mengalami tren penurunan ditahun-tahun berikutnya sampai terakhir turun drastis di tahun 2018 sebesar 47\% atau hanya menyentuh angka 75 untuk perkara peninjauan kembali.

Penumpukan-penumpukan perkara setiap tahunnya dapat dikurangi sehingga grafik yang ditujukkan bisa merangsek turun. Suatu hal yang dilematis apabila penumpukan perkara ini mampu diselesaikan dengan rasio yang signifikan namun disisi lain masih sedikit Mahkamah Agung menciptakan sebuah putusan yang 
mendalam, elaboratif dan bersifat landmark decisions karena tuntutan untuk menyelesaikan penumpukan dan beban perkara.

Tahun 2017 dalam laporan tahunannya Mahkamah Agung melaporkan setidaknya ada 12 putusan yang bersifat penting (landmark decissions). Salah satu dari 12 putusan tersebut ada satu putusan yang melahirkan sebuah kaidah baru yang berbunyi:28

Apabila bukti (novum) yang dijadikan rujukan pada putusan Peninjauan Kembali 1 untuk mengabulkan gugatan, dikemudian hari ternyata Bukti (novum) tersebut dinyatakan sebagai surat palsu atau yang dipalsukan oleh Putusan Peradilan umum (yang telah berkekuatan hukum tetap), maka putusan Peradilan umum tersebut dapat dijadikan dasar untuk membatalkan Putusan Peninjauan Kembali 1 melalui mekanisme Peninjauan Kembali 2.

Penerapan hukum oleh hakim lewat kaidah diatas yang secara sengaja menyimpangi eksplisit verbis bahkan asas-asas universal dalam hukum acara perdata, merupakan hasil rechtvinding oleh hakim demi terciptanya keadilan. Satu sisi putusan tersebut dipilih sebagai landmark decission dari beberapa putusan yang telah dihasilkan oleh Mahkamah Agung, disisi lain putusan tersebut juga menegasikan sebagian prinsip-prinsip hukum acara terkhusus hukum acara perdata, sehingga menjadi penting merekontruksi putusan tersebut dalam bingkai konsep upaya hukum peninjaun kembali. Kemudian semua ini dimaknai sebagai ikhtiar bersama dalam menemukan ius constituendum atau hukum yang dicita-citakan.

\section{Alasan Peninjauan Kembali Kedua dalam Putusan Mahkamah Agung Nomor 154/PK/TUN/ 2016}

Putusan Mahkamah Agung Nomor $1122 \mathrm{~K} / \mathrm{Pid} / 2015$, tanggal 30 September 2015, juncto Putusan Pengadilan Tinggi Bandung Nomor 120/Pid/2015/PT. BDG tanggal 25 Mei 2015 juncto Putusan Pengadilan Negeri Bandung Nomor 1530/Pid.B/2014/PN.BDG tanggal 23 Maret 2015 yang menyatakan Terdakwa Dra. Rd. Ridha Faridha Rukmiati Siti Jubaedah terbukti secara sah dan meyakinkan bersalah melakukan

28 Putusan Mahkamah Agung Nomor 154/PK/TUN/2016 
tindak pidana Turut Serta Menggunakan surat palsu atau yang dipalsukan, surat yang dinyatakan palsu atau yang dipalsukan.

Surat-surat yang dinyatakan palsu oleh putusan pengadilan sebagaimana disampaikan diatas merupakan novum yang dijadikan bukti dalam PK pertama yang menghasilkan Putusan Mahkamah Agung Nomor 35/PK/TUN/2009, sehingga ada dua putusan badan peradilan yang telah berkekuatan hukum tetap, dan kemuadian dua putusan itulah yang dijadikan hakim untuk menerima pengajuan permohonan peninjauan kembali.

Majelis PK kedua berpendapat Peninjauan Kembali ke-2 dapat diterima karena terdapat 2 (dua) Putusan Badan Peradilan yang berkekuatan hukum tetap yang bertentangan yang diketahui oleh Pemohon Peninjauan Kembali sejak menerima Surat dari Ketua Pengadilan Negeri Bandung pada tanggal 30 Maret 2016 perihal Permohonan Fotokopi Putusan Mahkamah Agung Nomor 1122 K/Pid/2015, tanggal 30 September 2015, juncto Putusan Pengadilan Tinggi Bandung Nomor 120/Pid/2015/PT. BDG tanggal 25 Mei 2015 juncto Putusan Pengadilan Negeri Bandung Nomor 1530/Pid.B/2014/PN.BDG tanggal 23 Maret 2015 yang menyatakan Terdakwa Dra. Rd. Ridha Faridha Rukmiati Siti Jubaedah terbukti secara sah dan meyakinkan bersalah melakukan tindak pidana Turut Serta Menggunakan surat palsu atau yang dipalsukan, surat yang dinyatakan palsu atau yang dipalsukan

Majelis dalam putusan perkara pidana di PN Bandung itu menyatakan Ridha Faridha Rukmiati Siti Jubaedah terbukti secara sah dan meyakinkan bersalah melakukan tindak pidana turut serta menggunakan surat palsu atau dipalsukan. Majelis PK kedua mencatat ada 3 surat yang dipalsukan. Pertama, putusan PN Bandung No 11.48 tanggal 16 September 1948. Kedua, penetapan Ketua PN Bandung No 11/1948 juncto 234/1954 juncto 437/1954 tertanggal 25 Juli 1971. Ketiga, keterangan panitera PN Bandung No 16/1967 tanggal 10 Agustus 1967.

Ketiga surat yang dipalsukan itu dijadikan dasar majelis hakim dalam pertimbangan hukumnya untuk memutus putusan MA No. 35 PK/TUN/2009 tertanggal 15 September 2009. Majelis PK kedua menggunakan hal itu sebagai dasar untuk membatalkan putusan PK kesatu dan mengabulkan PK kedua. 


\section{Rasionalisasi Novum Palsu dalam Pasal 67 Undang-Undang Nomor 3 Tahun 2009 Tentang Perubahan Kedua Atas Undang-Undang Nomor 14 Tahun 1985 Tentang Mahkamah Agung}

Penerapan Pasal 67 dalam Putusan Mahkamah Agung Nomor 154/PK/TUN/2016 yang juga tergolong sebagai landmark decision tahun 2017, dalam permohonannya para pemohon mendalilkan bahwa alasan mengapa PK tersebut diajukan karena telah ditemukan bukti-bukti yang dijadikan novum pada PK yang pertama telah terbukti dipalsukan oleh pihak yang dimenangkan pada PK pertama. Berangkat dari dalil tersebut Mahkamah berpendapat dalam pertimbangannya sebagai berikut:29

Peninjauan Kembali ke-2 dapat diterima karena terdapat 2 (dua) Putusan Badan Peradilan yang berkekuatan hukum tetap yang bertentangan yang diketahui oleh Pemohon Peninjauan Kembali sejak menerima Surat dari Ketua Pengadilan Negeri Bandung pada tanggal 30 Maret 2016 perihal Permohonan Fotokopi Putusan Mahkamah Agung Nomor 1122 K/Pid/2015, tanggal 30 September 2015, juncto Putusan Pengadilan Tinggi Bandung Nomor 120/Pid/2015/PT. BDG tanggal 25 Mei 2015 juncto Putusan Pengadilan Negeri Bandung Nomor 1530/Pid.B/2014/PN.BDG tanggal 23 Maret 2015 yang menyatakan Terdakwa Dra. Rd. Ridha Faridha Rukmiati Siti Jubaedah terbukti secara sah dan meyakinkan bersalah melakukan tindak pidana Turut Serta Menggunakan surat palsu atau yang dipalsukan, surat yang dinyatakan palsu atau yang dipalsukan.

Bicara alasan dapat diterimanya PK, juga bicara mengenai validitas hukumnya, sehingga rujukan utama dalam acara perdata untuk dapat diterima PK terdapat dalam Pasal 67 UU MA. Berikut bunyi pasalnya:30

29 Putusan Mahkamah Agung Nomor 154/PK/TUN/2016

30 Pasal 67 Undang-Undang Nomor 3 Tahun 2009 Tentang Perubahan Kedua Atas Undang-Undang Nomor 14 Tahun 1985 Tentang Mahkamah Agung (Lembaran Negara Republik Indonesia Tahun 2009 Nomor 3, Tambahan Lembaran Negara Republik Indonesia Nomor 4958) 


\section{Pasal 67}

Permohonan peninjauan kembali putusan perkara perdata yang telah memperoleh kekuatan hukum tetap dapat diajukan hanya berdasarkan alasan-alasan sebagai berikut:

a. apabila putusan didasarkan pada suatu kebohongan atau tipu muslihat pihak lawan yang diketahui setelah perkaranya diputus atau didasarkan pada bukti-bukti yang kemudian oleh hakim pidana dinyatakan palsu;

b. apabila setelah perkara diputus, ditemukan surat-surat bukti yang bersifat menentukan yang pada waktu perkara diperiksa tidak dapat ditemukan;

c. apabila telah dikabulkan suatu hal yang tidak dituntut atau lebih dari pada yang dituntut;

d. apabila mengenai sesuatu bagian dari tuntutan belum diputus tanpa dipertimbangkan sebab-sebabnya;

e. apabila antara pihak-pihak yang sama mengenai suatu soal yang sama, atas dasar yang sama oleh Pengadilan yang sama atau sama tingkatnya telah diberikan putusan yang bertentangan satu dengan yang lain;

f. apabila dalam suatu putusan terdapat suatu kekhilafan Hakim atau suatu kekeliruan yang nyata.

Ada 3 analisa terkait penerapan alasan yang dihadirkan lewat putusan tersebut dengan pisau analisis Pasal 67 UU MA. Pertama, sekilas membaca pendapat Mahakamah mengenai diterimanya PK tersebut didasarkan pada alasan, ada dua putusan badan peradilan yang telah berkekuatan hukum tetap dan saling bertentangan, sehingga rujukan utamanya adalah Pasal 67 huruf (e) yang berbunyi:31 "apabila antara pihak-pihak yang sama mengenai suatu soal yang sama, atas dasar yang sama oleh Pengadilan yang sama atau sama tingkatnya telah diberikan putusan yang bertentangan satu dengan yang lain". Sebenarnya ketika menelisik lebih mendalam terhadap pasal ini, tidak berlaku bebas dan menyeluruh pada semua putusan badan peradilan. Yahya Harahap memberikan limitasi terhadap pasal ini kedalam beberapa kriteria, sehingga putusan 
tersebut memenuhi unsur Pasal 67 huruf (e). Kriteria pasal tersebut adalah sebagai berikut:32

1. Terdapat dua atau lebih putusan yang saling bertentangan;

2. Pihak yang terlibat dalam putusan yang saling bertentangan tresebut adalah sama;

3. Soal dan dasar yang digunakan sama;

4. Putusan yang terakhir dan bertentangan itu telah BHT;

5. Diperiksa oleh pengadilan yang sama atau sama tingkatnya.

Antara kriteria angka 1 sampaiangka 4 telah terpenuhi, namun untuk kriteria angka 5 telah disyaratkan, bahwa putusan yang dijatuhkan harus oleh pengadilan yang sama (baik sama-sama kompetensi relatifnya maupun sama-sama lingkungan peradilannya) dan pengadilan yang sama tingkatannya. Putusan Mahkamah Agung Nomor $1122 \mathrm{~K} / \mathrm{Pid} / 2015$ juncto Putusan Pengadilan Tinggi Bandung Nomor 120/Pid/2015/PT. BDG juncto Putusan Pengadilan Negeri Bandung Nomor 1530/Pid.B/2014/PN.BDG yang telah berkekuatan hukum tetap, coba di sandingkan dengan Putusan Mahkamah Agung Nomor 35/PK/TUN/2009 tidak sama tingkatannya. Secara mutatis-mutandis putusan tersebut tidak memenuhi syarat bahwa putusan harus dijatuhkan oleh pengadilan yang sama tingkatannya.

Kedua, karena dalam pertimbangan hakim dalam menerima PK tersebut juga berkaitan erat dengan adanya sitilah novum, sehingga alasan tersebut bersinggungan erat pula dengan Pasal 67 huruf (b) yang lebih dikenal dengan istilah novum. Pasal tersebut berbunyi:33 "apabila setelah perkara diputus, ditemukan surat-surat bukti yang bersifat menentukan yang pada waktu perkara diperiksa tidak dapat ditemukan;".

Sejatinya istilah novum dalam acara perdata terbatas pada alat bukti surat yang telah ada sebelumnya namun tidak ditemukan pada saat pemeriksaan sampai perkara tersebut telah diputus dan berkekuatan hukum tetap.34 Fakta persidangan mengungkapkan

32 M. Yahya Harahap, Kekuasaan Mabkamah Agung Pemeriksaan Kasasi dan Peninjauan Kembali Perkara Perdata (Jakarta: Sinar Grafika, 2008),

33 Ibid

34 M. Yahya Harahap, Kekuasaan Mabkamah Agung Pemeriksaan Kasasi dan Peninjauan Kembali Perkara Perdata, 453-457 
bahwa sejatinya yang menjadi bukti utama telah terpampang nyata, namun pada akhirnya dinyatakan palsu oleh pengadilan, sehingga tidak dalam keadaan baru atau bersifat novum.

Ketiga, pintu masuk yang menjadi pertimbangan hakim dalam menerima PK tersebut adalah adanya alat bukti yang secara sah dan menyakinkan telah dipalsukan dengan dibuktikan lewat putusan pengadilan in casu Putusan Mahkamah Agung Nomor 1122 K/Pid/2015 juncto Putusan Pengadilan Tinggi Bandung Nomor 120/Pid/2015/PT. BDG juncto Putusan Pengadilan Negeri Bandung Nomor 1530/Pid.B/2014/PN.BDG, sehingga dapat dikatakan bahwa alasan PK sebagaimana disampaikan diatas masuk dalam kriteria Pasal 67 huruf (a) UU MA, yang berbunyi sebagi berikut:35 "apabila putusan didasarkan pada suatu kebohongan atau tipu muslihat pihak lawan yang diketahui setelah perkaranya diputus atau didasarkan pada bukti-bukti yang kemudian oleh hakim pidana dinyatakan palsu;". Adapun kriteria yang disyarakat dalam pasal tersebut adalah sebagai berikut:36

1. Putusan didasarkan pada suatu kebohongan atau tipu muslihat pihak lawan, dan kebohongan atau tipu muslihat itu diketahui setelah perkaranya putus, atau;

2. Putusan didasarkan pada bukti-bukti yang kemudian oleh hakim pidana dinyatakan palsu.

Pertama, bukti-bukti yang digunakan hakim dalam pertimbangnnya memutus PK yang pertama dengan produk Putusan Mahkamah Agung Nomor 35/PK/TUN/2009 telah diketahui dipalsukan setelah pemohon menerima salinan putusan tertanggal 30 Maret 2016 dari Ketua Pengadilan Negeri Bandung. Kedua, bahwa bukti-bukti tersebut telah secara sah dan menyakinkan dinyatakan palsu oleh Pengadilan Negeri Bandung dan diyakinkan kembali lewat Putusan Pengadilan Tinggi Bandung dan lewat putusan Kasasi oleh Mahkamah Agung.

Terhadap analisa penerapan pasal yang coba disandingkan dengan alasan yang digunakan hakim dalam menerima PK tersebut,

35 Pasal 67 huruf a Undang-Undang Nomor 3 Tahun 2009 Tentang Mahkamah Agung

36 M. Yahya Harahap, Kekuasaan Mabkamah Agung Pemeriksaan Kasasi dan Peninjauan Kembali Perkara Perdata, 450-452 
lebih condong masuk dalam kriteria Pasal 67 huruf (a) yang berbunyi: "apabila putusan didasarkan pada suatu kebohongan atau tipu muslihat pihak lawan yang diketahui setelah perkaranya diputus atau didasarkan pada bukti-bukti yang kemudian oleh hakim pidana dinyatakan palsu"

\section{Analisis Yuridis Peninjauan Kembali Kedua dalam Perkara Perdata Berdasarkan Alasan Novum Palsu}

Konsistensi Mahkamah Agung dalam penegakkan kepastian hukum peninjauan kembali sebagai upaya hukum luar biasa telah terbukti dari beberapa fakta. Pertama, perubahan Undang-Undang Mahkamah Agung yang menerangkan validitas hukum PK terbatas satu kali dalam Pasal 66 UU MA tidak sama sekali dirubah meskipun UU MA telah mengalami tiga kali perubahan. Kedua, lahirnya SEMA Nomor 10 Tahun 2009 merupakan bentuk pengendalian Mahkamah Agung terhadap praktek peninjauan kembali yang sering dilakukan lebih dari satu kali, sehingga memerintahkan kepada Pengadilan tingkat pertama dan tingkat banding untuk tidak menerima PK yang kedua selain ada dua putusan PK yang saling bertentangan meskipun berbeda lingkungan peradilan. Selain upaya pengendalian lewat hadirnya SEMA, MA juga mengendalikannya lewat pengaturan yang konsisten dalam sistem kamar sebagai upaya memperkuat dalam menjalankan fungsinya sebagai judex jurist agar disparitas putusan yang seringkali mencolok dihadirkan oleh MA termasuk disparitas putusan peninjauan kembali dapat ditekan secara terstruktur, sistematis dan massive. Ketiga, Munculnya SEMA 07 Tahun 2014 merupakan respon terhadap Putusan Mahkamah Konstitusi Nomor 34/PUU-XI/2013 yang menyatakan bahwa Pasal 268 ayat (3) undang-undang Nomor 8 Tahun 1981 tentang Hukum Acara Pidana yang menyatakan, "(3) Permintaan peninjauan kembali atas suatu putusan hanya dapat dilakukan satu kali saja" tidak mempunyai kekuatan hukum mengikat. Seakan tidak sejalan terhadap apa yang telah diputuskan MK meskipun putusan MK bersifat final dan mengikat, MA konsisten terhadap pendirian awal bahwa PK terbatas satu kali. Sikap tegas MA terhadap pembatasan PK yang hanya bisa diajukan satu kali, sejatinya merupakan konsekuensi logis dari aspek ratio legis peninjauan kembali yang di dalamnya terkandung maksud litis finiri oportet, sehingga timbul 
respon yang demikian bahkan untuk perkara pidana. Apalagi dalam konteks ini menyinggung penyelesaian perkara perdata yang sejatinya validitas hukum PK terbatas satu kali berbeda dengan yang telah dinyatakan tidak mempunyai kekuatan hukum mengikat oleh MK lewat putusan tersebut.

Mengingat praktek hukum yang sulit bahkan hampir dapat dipastikan bahwa praktek hukum seringkali menyimpangi aturan hukum yang berlaku, Mahkamah Agung memberi jalan keluar terhadap penerapan PK dapat dilakukan lebih dari dua kali dengan syarat sebagai berikut:37

Apabila suatu obyek perkara terdapat 2 (dua) atau lebih putusan peninjauan kembali yang bertentangan satu dengan yang lain baik dalam perkara perdata maupun perkara pidana dan diantaranya ada yang diajukan permohonan peninjauan kembali agar permohonan peninjauan kembali tersebut diterima dan berkas perkaranya tetap dikirim ke Mahkamah Agung.

Terjadi jarak antara kehendak SEMA Nomor 10 Tahun 2009 dengan pertimbangan hakim yang menerima PK ke-2 dalam perkara perdata dengan alasan penemuan alat bukti (novum) yang dinyatakan palsu oleh pengadilan pidana sebagaimana tercatat dalam Putusan Mahkamah Agung Nomor 154/PK/TUN/2016. Secara subtansial penemuan hukum lewat putusan ini dapat diakui sebagai teroboson hukum yang progresif, namun secara prosedural hal tersebut tidak bisa dibenarkan karena menciderai aspek ratio legis peninjauan kembali dan asas kepastian hukum beserta derivasi-derivasinya.

\section{Penutup}

Alasan diterimanya Peninjauan Kembali kedua dalam perkara Perdata didasarkan pada penemuan alat bukti (novum), yang dinyatakan palsu oleh hakim Pidana Pengadilan Negeri Bandung (yang telah berkekuatan hukum tetap). Alasan tersebut masuk dalam kriteria Pasal 67 huruf (a) yang berbunyi: "apabila putusan didasarkan pada suatu kebohongan atau tipu muslihat pihak lawan yang diketahui setelah perkaranya diputus atau didasarkan pada bukti-bukti yang kemudian oleh hakim pidana dinyatakan palsu",

37 Putusan Mahkamah Agung Nomor 154/PK/TUN/2016 
bukan tergolong pada alasan telah ditemukannya novum atau alasan ada dua putusan badan peradilan yang saling bertentangan.

Peninjauan Kembali kedua dalam perkara Perdata maupun Pidana telah diberi mekanisme yang hanya terbatas pada alasan ada dua putusan Peninjauan Kembali, baik dalam satu lingkungan peradilan maupun di luar lingkungan peradilan, namun antara satu dan lainnya saling berkelindan (sebagaimana digariskan dalam SEMA Nomor 10 Tahun 2009), sehingga selain alasan tersebut Mahkamah Agung belum pernah mengeluarkan kebijakan terkait mekanisme Peninjauan Kembali ke-2, termasuk dengan alasan telah ditemukannya alat bukti (novum) yang secara sah dan menyakinkan dinyatakan palsu oleh pengadilan umum.

\section{Daftar Pustaka}

Harlen Sinaga, Hukum Acara Perdata dengan Pemahaman Hukum Materiil (Jakarta: Erlangga, 2015).

M. Yahya Harahap, Kekuasaan Mabkamah Agung Pemeriksaan Kasasi dan Peninjauan Kembali Perkara Perdata (Jakarta: Sinar Grafika, 2008).

M. Yahya Harahap, Ruang Lingkup Permasalahan Eksekusi Bidang Perdata (Jakarta: Sinar Grafika, 2005), Edisi Kedua, Cetakan Pertama

Mukti Arto, Praktek Perkara Perdata pada Pengadilan Agama. (Yogyakarta: Pustaka Pelajar, 1996), cet. IV.

Mukti Arto, Upaya Hukum Kasasi dan Peninjanan Kembali Perkara Perdata Agama, Ekonomi Syariah dan Jinayah. (Depok: Prenadamedia Group, 2018).

Ramlan Subekti, Hukum Acara Perdata. (Bandung: Bina Cipta, 1989). Sudikno Mertokusumo, Hukum Acara Perdata Indonesia. (Yogyakarta: Liberty, 2009), Edisi VIII, Cetakan I.

Sunarto. Peran Aktif Hakim dalam Perkara Perdata. Jakarta: (Prenadamedia Group, 2015), Cet. II.

Sutantio, Ny. Retnowulan dan Oeripkartawinata, Iskandar, Hukum Acara Perdata dalam Teori dan Praktek. (Bandung: Mandar Maju, 1997), cet. VIII.

Swantoro, Herri. Harmonisasi Keadilan dan Kepastian dalam Peninjauan Kembali. Depok: Prenadamedia Group, 2017. 
Taufik, Moh.Pokok-Pokok Hukum Acara Perdata. Jakarta: Rineka Cipta, 2009.

Wirjono Prodjodikoro. Hukum Acara Perdata di Indonesia. Bandung, Sumur, 1982.

Tania Sourdin dan Naomi Burstyner, 'Justice Delayed Is Justice Denied', dalam Journal of Monash University, 2013.

UU Nomor 3 Tahun 2009 Tentang Perubahan Kedua Atas UndangUndang Nomor 14 tahun 1985 Tentang Mahkamah Agung, (Lembaran Negara Republik Indonesia Tahun 2009 Nomor 3, Tambahan Lembaran Negara Republik Indonesia Nomor 4958).

Putusan Mahkamah Konstitusi Nomor 34/PUU-XI/2013.

Putusan Mahkakamah Agung Nomor 154 PK/TUN/2016.

Surat Edaran Mahkamah Agung Nomor 10 Tahun 2009 Tentang Pengajuan Permohonan Peninjauan Kembali (Nomor Surat: 10/Bua.6/Hs/SP/VI/2009).

Surat Edaran Mahakamah Agung Nomor 7 Tahun 2014 Tentang Pengajuan Permohonan Peninjauan Kembali Dalam Perkara Pidana (Nomor Surat: 165/Bua.6/Hs/SP/XII/2014)

Kumpulan Surat Edaran Mahkamah Agung, diakses dari: http://bawas.mahkamahagung.go.id/portal/surat-edaranmahkamah-agung, pada tanggal 26 Juni 2019, Jam 04.23

Statistik Data Perkara Mahkamah Agung diakses dari: http://leip.or.id/statistik-data-perkaramahkamah-agung, pada tanggal 01 April 2019, pukul 07:28 WIB. 